\title{
Quantitative Arsenic Speciation in Two Species of Earthworms from a former Mine Site
}

\author{
Michael J. Watts, ${ }^{* a}$ Mark Button, ${ }^{a, b, c}$ Tim S. Brewer $^{\mathrm{b}}$, Gawen R. T. Jenkin ${ }^{\mathrm{b}}$ and Chris F. Harrington ${ }^{c}$ \\ Receipt/Acceptance Data [DO NOT ALTER/DELETE THIS TEXT] \\ ${ }_{5}$ Publication data [DO NOT ALTER/DELETE THIS TEXT] \\ DOI: 10.1039/b000000x [DO NOT ALTER/DELETE THIS TEXT]
}

The relationship between the total arsenic concentration and the chemical speciation of arsenic in two species of earthworm (Lumbricus rubellus and Dendrodillus rubidus) in relation to the host soil, was investigated for 13 sites of varying arsenic content, including a

${ }_{10}$ background level garden soil and a former mine site at the Devon Great Consols, UK.

Earthworms were collected with the host soil (As soil concentration range $16-12,466 \mathrm{mg} \mathrm{kg}^{-1}$ dry weight) and measured for their total arsenic (concentration range 7 - $595 \mathbf{~ m g ~ k g}^{-1}$ dry weight) using inductively coupled plasma mass spectrometry (ICP-MS). A methanol-water mixture was used to extract arsenic species from the earthworms prior to determination of

15 the individual arsenic species by a combination of anion and cation exchange high performance liquid chromatography coupled to inductively coupled plasma mass spectrometry (HPLC-ICP-MS). A gradient elution anion exchange method is presented whereby nine arsenic species could be measured in one sample injection. Arsenic species were identified by comparison of retention times and sample spiking with known standards 20 and a fully characterised seaweed extract. Arsenic was generally present in the earthworm as arsenate $\left(\mathrm{As}^{\mathrm{V}}\right)$ or arsenite $\left(\mathrm{As}^{\mathrm{III}}\right)$ and arsenobetaine (AB). Methylarsonate (MA), dimethylarsinate (DMA) and three arsenosugars (glycerol, phosphate, sulphate) were present as minor constituents. These results are discussed in relation to the mechanisms for coping with exposure to soil bound arsenic.

\section{${ }_{25}$ Introduction}

Sentinel organisms such as earthworms are often employed as an alternative risk assessment method for the biomonitoring of anthropogenic and geogenic toxins, particularly arsenic in the terrestrial environment ${ }^{1}$. Earthworms are of particular use in 30 monitoring the potential exposure of single or multiple soil contaminants as they maintain constant contact with both the solid and liquid phase of soil. In this way, earthworms can be used in partitioning and chemical speciation models to assess bioavailability $^{2-5}$ and the basis for toxic effects ${ }^{6,7}$.

35 The study of the occurrence, accumulation and speciation of arsenic in the earthworm can help to provide more accurate assessments of the risk of exposure in both an ecological and human health context ${ }^{8}$. The behavioural response of earthworms to soil contaminants directly influences the degree 40 to which exposure results in toxic effects. For example, Lumbricus rubellus reside in the upper soil horizon $(\sim 20 \mathrm{~cm})$ and has been shown to discriminate between soils with concentration of sodium arsenate above $5000 \mathrm{mg} \mathrm{kg}^{-1}$. Dendrodillus rubidus is known to inhabit arsenic 45 contaminated soils and mine waste ${ }^{10-12}$, such as at the Devon \footnotetext{
${ }^{a}$ British Geological Survey, Nottingham, UK. Fax: 44(0)115 9363329; Tel:44(0)115 9363042; E-mail: mwatts@bgs.ac.uk

${ }^{b}$ University of Leicester, Department of Geology, University Road, Leicester, UK. Fax: 44(0)1162523918; Tel: 44(0)116 2523611;

${ }^{c}$ University of Leicester, Biocentre, University Road, Leicester, UK. Fax: 44(0)116 2231840; Tel: 44(0)116 2231824; E-mail: cfh7@leicester.ac.uk $\dagger$ Electronic Supplementary Information (ESI) available: [details of any supplementary information available should be included here]. See http://dx.doi.org/10.1039/b000000x/
}

Great Consols (DGC) in Devon, $\mathrm{UK}^{9,13}$. The varied toxicities of arsenic compounds in the terrestrial environment emphasises the need to provide more information about the chemical form of arsenic in both the sentinel organism and 50 soil in order to assess the risk of exposure to arsenic.

A major problem of identifying and quantifying arsenic species in solid samples, is an appropriate extraction method that will avoid transformations and maintain the integrity of the arsenic species. The extraction recovery may be 55 influenced by the matrix or be species dependent. The lack of certified reference materials for arsenic species is a major hindrance for the development and validation of extraction methods. Methanol-water extractions have been widely used for the extraction of arsenic species from biota samples, ${ }_{60}$ including earthworms ${ }^{14-17}$. Arsenite and arsenate were demonstrated as the main extractable inorganic arsenicals in L. rubellus ${ }^{15,18}$. In most cases arsenobetaine $(\mathrm{AB})$ is present as the primary organic arsenic species with methylarsonate (MA) present at trace levels ${ }^{14,18}$. However, Geiszinger et al. ${ }_{65}(2002)^{19}$ found that a major arsenic containing compound in the earthworm extract $(9: 1 \mathrm{v} / \mathrm{v}$ methanol:water $)$ was the phosphate arsenosugar, accounting for approximately $55 \%$ of the total arsenic in the extract of the earthworm, with the glycerol arsenosugar, dimethylarsinate (DMA), 70 methylarsonate (MA), arsenate $\left(\mathrm{As}^{\mathrm{V}}\right)$ and arsenite $\left(\mathrm{As}^{\mathrm{III}}\right)$ present as minor constituents. The two other arsenosugars were also detected in the cast extract, with some $\mathrm{As}^{\mathrm{III}}$ and $\mathrm{As}^{\mathrm{v}}$. 
The measurement of arsenic species in environmental and 75 biological samples at trace levels generally requires an on-line approach to the separation of arsenic species. HPLC is generally used for analyte separation, commonly using anion or cation exchange for organic compounds to identify $\operatorname{arsenosugars}^{33}$. ICP-MS is commonly coupled to HPLC ${ }^{15,20-}$ ${ }_{80}{ }^{22}$ for analyte detection. ICP-MS is suitable for aqueous samples and aqueous extracts of environmental and biological samples $^{23}$. ICP-MS as the elemental detector offers the possibility of multielemental, multispecies determinations within the same sample measurement ${ }^{24-27}$.

85 The aim of this study was to characterise the speciation of arsenic in earthworm populations from highly contaminated and uncontaminated soils, by determining the arsenic metabolites and potential differences between different species of earthworms. The speciation analysis of the samples 90 was carried out using a high throughput HPLC system, incorporating anion exchange gradient elution and cation exchange isocratic elution.

\section{Experimental \\ ${ }_{95}$ Sampling Sites}

Devon Great Consols (DGC) is one of many former mining sites in the South West of England and is situated on the east bank of the River Tamar in the Tavistock district of Devon (sheet number GR: 426 735). Arsenic concentrations in soils 100 found in and around the mine vary significantly depending on their proximity to the main tailings ranging from 249 to $34,000 \mathrm{mg} \mathrm{kg}^{-1} 9,13$. Bioaccessibility of arsenic in soils at the mine is reportedly low due to arsenic binding to an iron and sulphide rich source such as arsenopyrite ${ }^{13}$ yet still represents 105 a significant risk to health due to the elevated arsenic levels. In addition, a Nottingham garden with soil arsnic levels below the UK Department for Food and Rural Affairs (DEFRA) Soil Guideline Value (SGV) of $20 \mathrm{mg} \mathrm{kg}^{-1}$ was also selected to provide samples of a lower concentration range.

110

\section{Earthworm and Soil Sample Collection}

The soil surface $(0-20 \mathrm{~cm})$ in a $1 \mathrm{~m}^{2}$ grid was overturned with a spade and placed onto plastic sheeting allowing individual earthworms to be handpicked from their host soil.

${ }_{115}$ Specimens were promptly sorted according to species, thoroughly rinsed with deionised water and placed in ventilated tubes with moist filter paper to begin the depuration of gut contents. Earthworms were depurated for a minimum of 48 hours, as shorter time periods were unlikely to remove all 120 soil particles in larger species such as L. rubellus. ${ }^{10}$ Filter paper was changed daily and cast material collected. Depuration was halted when no more cast material was deposited on the filter paper. A small selection of earthworms was dissected and the gut contents examined under a 125 microscope to ensure no soil particles remained. Approximately 10 to 25 earthworms were collected at each sampling. Depurated earthworms were thoroughly rinsed with deionised water, euthanased humanely and dried in a low temperature oven $\left(50{ }^{\circ} \mathrm{C}\right)$ before homogenisation as a 130 composite sample in a ceramic mortar and pestle for each collection point. All experiments were performed in compliance with the relevant laws and institutional guidelines.
The use of earthworms did not require ethical approval from any institutional committees. The host soil from the $1 \mathrm{~m}^{2}$ grid 135 in which the earthworms were collected from was turned over using a spade to mix and, approximately 0.5 to $1 \mathrm{~kg}$ of a composite soil sample was placed into paper sample collection bags and dried at room temperature. Soil were sieved to $<250 \mu \mathrm{m}$ fraction and stored in air and light sealed 140 containers prior to analysis. Earthworm cast material was collected following depuration, dried $\left(50{ }^{\circ} \mathrm{C}\right)$ and ground into a powder with a mortar and pestle.

\section{Standards and Reagents}

${ }_{145}$ All reagents used were analytical grade or better quality. All aqueous solutions were prepared using deionised water (18.2 $\mathrm{M} \Omega$ Millipore, UK). Arsenite $\left(\mathrm{As}(\mathrm{OH})_{3}\right)$, arsenate $\left(\mathrm{AsO}(\mathrm{OH})_{3}, \quad\right.$ Fisher, UK), monomethylarsonic acid $\left(\mathrm{CH}_{3} \mathrm{AsO}(\mathrm{OH})_{2}\right.$, Sigma-Aldrich, UK), dimethylarsinic acid $150\left(\mathrm{CH}_{3}\right)_{2} \mathrm{AsO}(\mathrm{OH})$, Greyhound, UK) and arsenobetaine $\left(\left(\mathrm{CH}_{3}\right)_{3} \mathrm{As}^{+} \mathrm{CH}_{2} \mathrm{COO}^{-}\right.$, LGC, UK) were used for the preparation of standards for arsenic speciation analysis. An algal extract containing four different arsenosugars and characterised previously by Madsen et al. (2000) $)^{28}$ (kindly

155 donated by Professor K. Francesconi, University of Graz) was used to validate the preparation of four isolated arsenosugar standards (names of arsenosugars taken from Francesconi et al., (2004) ${ }^{21}$ : glycerol, phosphate, sulphonate, sulphate) from a seaweed extract. Figure 1 illustrates the structure of the four 160 arsenosugar compounds. These arsenosugar standards were prepared according to methods published by Madsen et al. $2000^{28}$. Methanol (Fisher Scientific, UK) was employed as a solvent in the extraction procedure. Ammonium nitrate $\left(\mathrm{NH}_{4} \mathrm{NO}_{3}\right.$, Sigma-Aldrich, UK) was used as the mobile phase 165 for gradient anion exchange separation of arsenic species and pyridine (Rathburn, UK) was used for isocratic cation exchange separation. Concentrated nitric acid, hydrofluoric acid and $30 \% \mathrm{v} / \mathrm{v}$ hydrogen peroxide (BDH Aristar, UK) were used for the dissolution of earthworms and soil samples. ${ }_{170}$ Calcium chloride (Fisher Scientific, UK) was used for the measurement of soil $\mathrm{pH}$.

\section{Total Digestion of Earthworm}

Microwave assisted (CEM MARS5, CEM Corporation, UK) 175 dissolution of the earthworms was performed on $0.1 \mathrm{~g}$ of earthworm homogenate (dry weight). $10 \mathrm{ml}$ of concentrated nitric acid and $100 \mu \mathrm{l}$ of hydrofluoric acid was added and allowed to stand for 30 minutes. Following an initial heating programme (ramp to $100{ }^{\circ} \mathrm{C}$ over 5 minutes then hold for 5 180 minutes, ramp to $200{ }^{\circ} \mathrm{C}$ over 5 minutes and hold for 20 minutes $)$ the vessels were allowed to $\operatorname{cool}\left(<50{ }^{\circ} \mathrm{C}\right)$ and then 1 $\mathrm{ml}$ of $30 \% \mathrm{H}_{2} \mathrm{O}_{2}$ was added. The vessels were sealed and microwaved for a second cycle (same program). After cooling, the sample solutions were transferred to PTFA ${ }_{185}$ Savellex containers and evaporated to dryness on a hotplate $\left(100{ }^{\circ} \mathrm{C}\right)$ to reduce the presence of organic compounds that could form possible polyatomic interferences by ICP-MS measurement. Samples were reconstituted by addition of $2 \mathrm{ml}$ $50 \% \mathrm{v} / \mathrm{v}$ nitric acid, heated at $50{ }^{\circ} \mathrm{C}$ for 30 minutes and then 190 made up to $10 \mathrm{ml}$ with deionised water. This final stage reduced the dilution of the acid content required for ICP-MS 
measurement $(<2.5 \% \mathrm{v} / \mathrm{v})$. The method described is a validated routine procedure for the dissolution of biological samples. The method accuracy was monitored using a 195 certified reference material, CRM 627 tuna fish tissue (BCR, Brussels). Mean total arsenic recoveries of $96 \pm 7 \%(n=6)$ were obtained, compared to the certified value. The method precision expressed as the mean percentage difference $( \pm 1$ $\mathrm{SD})$ between duplicate samples was $1.7 \pm 0.9 \%(\mathrm{n}=4$ 200 duplicates).

\section{Soil Chemistry}

Soil $\mathrm{pH}$ was determined by $0.01 \mathrm{M}$ aqaeous $\mathrm{CaCl}_{2}(6.25 \mathrm{ml})$ to $0.25 \mathrm{~g}$ soil $(<250 \mu \mathrm{m}$ particle size $)$, mixed for 5 minutes and 205 left to stand for 15 minutes prior to analysis using a $\mathrm{pH}$ meter (Orion SA720, UK). Readings were checked at the start and end of the run using a $\mathrm{pH} 7$ buffer solution and in-house QC standard $(\mathrm{pH} \mathrm{7.3)}$. Total carbon in the soil was determined using a carbon / sulphur analyser (LECO CS230), 0.2 g (dry

210 weight) of each homogenised soil sample was weighed into a ceramic crucible for each determination. All carbon analyses were performed in triplicate. Loss on ignition (LOI) was also determined for each soil sample to provide an indication of the organic matter content. $1 \mathrm{~g}$ (dry weight) of each soil was 215 weighed into a glass crucible before heating to $450^{\circ} \mathrm{C}$ for 4 hours. The percentage weight reduction after heating was recorded.

\section{Soil Dissolution}

${ }_{220}$ Collected soils $(0.25 \mathrm{~g})$ and earthworm cast material $(0.1 \mathrm{~g})$ were prepared for total elemental measurements by ICP-MS based on a mixed acid digestion approach $\left(\mathrm{HF} / \mathrm{HNO}_{3} /\right.$ $\left.\mathrm{HClO}_{4}\right)^{29}$. Samples were weighed into PFA vials, acids added and heated on a temperature programmable graphite hot-block ${ }_{225}\left(80{ }^{\circ} \mathrm{C}\right.$ for $8 \mathrm{hrs}, 100{ }^{\circ} \mathrm{C}$ for $2 \mathrm{hrs}, 120^{\circ} \mathrm{C}$ for $1 \mathrm{hr}, 140{ }^{\circ} \mathrm{C}$ for 3 hrs, $160^{\circ} \mathrm{C}$ for $4 \mathrm{hrs}$ ). This mixture was used, rather than the more widely used aqua regia, as the hydrofluoric acid breaks down the silicate structure, except for a few accessory minerals to give an almost total digest and hence total

230 concentrations can be determined. Perchloric acid was used to breakdown more resistant minerals and ensure complete evaporation of the hydrofluoric acid. Once digested and evaporated, the sample was taken up in $2.5 \mathrm{ml}$ of concentrated nitric acid, heated at $50{ }^{\circ} \mathrm{C}$ for 30 minutes and then treated 235 with $30 \%(\mathrm{v} / \mathrm{v})$ hydrogen peroxide to avoid precipitation of meta-stable hydroxyl-fluorides, before being made up to volume $(25 \mathrm{ml})$ with deionised water to give a final solution of $5 \%$ nitric acid for analysis by ICP-MS. Certified reference materials were included with each batch of soil digestions as a 240 measure of quality control. These were NIST CRM 2710 Montana Soil I and NIST CRM 2711 Montana Soil II, and gave good recoveries of $98 \pm 4 \%(\mathrm{n}=6)$ and $91 \pm 3 \%(\mathrm{n}=$ 3 ), respectively, during the course of the study. The method precision expressed as the mean percentage difference $( \pm 1$ $\left.{ }_{245} \mathrm{SD}\right)$ between duplicate samples was $3.2 \pm 3.6 \%(\mathrm{n}=4$ duplicates).

\section{Sample Extraction}

This journal is (c) The Royal Society of Chemistry [year]
250 The extraction of arsenic species from the earthworms was facilitated using a methanol-water mixture. The most effective ratio of methanol to water, which extracted the greatest amount of arsenic from the freeze dried earthworm powders, was determined experimentally to be a 1:1 ratio ${ }^{30}$, 255 which is the usual approach for the extraction of arsenic species from marine organisms and algae ${ }^{31}$.

Homogenised earthworm powder $(0.25 \mathrm{~g})$ was weighed directly into $50 \mathrm{ml}$ polyethylene centrifuge tubes. $10 \mathrm{ml}$ of methanol:water $(1: 1 \mathrm{v} / \mathrm{v})$ was then added and the tubes shaken

260 on an orbital shaker at $175 \mathrm{rpm}$ for 4 hours. The extracts were centrifuged at $3000 \mathrm{rpm}$ for 10 minutes and the supernatant transferred to polypropylene bottles. A multi-step extraction was not employed as any additional arsenic contained in the second and subsequent extractions has been shown to be 265 accountable to the residual dissolved arsenic carried over from previous extractions. ${ }^{31}$ The sample solutions were evaporated to a syrup using a rotary evaporator before freeze drying. The freeze-dried residue was reconstituted in $10 \mathrm{ml}$ of deionised water and analysed immediately. Prior to extraction of 270 earthworm samples, the stability of arsenic species ( $\mathrm{As}^{\mathrm{III}}, \mathrm{As}^{\mathrm{V}}$, MA, DMA and AB) were established under the proposed extraction conditions by separately spiking earthworm powder material with each of the arsenic species. Recoveries of spiked arsenic species were $93 \pm 18 \%$, with no evidence of 275 interconversion between species (particularly between $\mathrm{As}^{\mathrm{III}}$ and $\mathrm{As}^{\mathrm{V}}$ ). Extraction efficiency was monitored using the CRM 627 tuna fish tissue (BCR, Brussels), A mean recovery of $77 \pm 0.3 \%(n=3)$ of the total arsenic value was obtained under the extraction conditions described. The method 280 precision expressed as the mean percentage difference $( \pm 1$ SD) between duplicate samples was $2.8 \pm 1.8 \%(\mathrm{n}=4$ duplicates).

\section{Instrumentation \\ Total Elemental Analysis}

The methanol extracts reconstituted in DI water, earthworm and soil digests were all analysed for trace metal contents using a Thermoelemental PQ ExCell ICP-MS. The standard 290 operating conditions were as follows: RF power $1350 \mathrm{~W}$; gas flow rates, coolant $131 \mathrm{~min}^{-1}$, auxiliary $0.91 \mathrm{~min}^{-1}$, nebuliser $0.931 \mathrm{~min}^{-1}$; spraychamber temperature $3{ }^{\circ} \mathrm{C}$; Meinhardt nebuliser. The instrument was tuned using a $1 \mu \mathrm{g}^{-1}$ Claritas PPT multielement tune solution 1 (GlenSpectra Reference ${ }_{295}$ Materials, UK). Data was acquired in peak jump mode with an acquisition of $3 \times 30$ seconds. Indium at a concentration of 10 $\mu \mathrm{g}^{-1}$ was used as an internal standard and was added to the sample stream via a t-piece.

\section{Arsenic Speciation}

A quaternary pump (GP50-2 HPLC Pump and an AS-50 autosampler (Dionex, USA) was directly coupled to an ICPMS (PQ ExCell, Thermoelemental, UK) for measurement of arsenic species, by connecting the analytical column to the 305 ICP nebuliser with PEEK tubing. The two instruments were coupled in such a way that the injection of each sample solution, via the Dionex AS-50 autosampler and subsequent measurement was synchronised automatically using the ICP- 
MS Plasmalab software, enabling reproducible sample 310 injections.

Two different eluent systems were used to separate the extracted arsenic species present in the earthworms, using an anion exchange column (PRP-X100, $250 \times 4 \mathrm{~mm}, 10 \mu \mathrm{m}$ ) with a guard cartridge of the same material or a cation 315 exchange column (PRP-X200, $250 \times 4 \mathrm{~mm}, 10 \mu \mathrm{m}$ ) with a guard cartridge of the same material (both Hamilton, USA). The first chromatographic separation (Figure 2a) was based on a modified gradient elution system developed by MartinezBravo et al. $(2000)^{24}$, which used a gradient between A: $4 \mathrm{mM}$ $320 \mathrm{NH}_{4} \mathrm{NO}_{3}$ and $\mathrm{B}: 60 \mathrm{mM} \mathrm{NH} \mathrm{NO}_{3}$, both adjusted to $\mathrm{pH} 8.7$ with ammonia. The flow rate was $1 \mathrm{ml} \min ^{-1}$, with the gradient as follows: $100 \%$ A 0 - 2 minutes; $100 \%$ B $3-6.5$ minutes; $100 \%$ A 7.5 - 10.75 minutes; $100 \%$ B $11-13$ minutes; $100 \%$ A 13.25 - 15 minutes. This method achieved 325 good separation for $\mathrm{As}^{\mathrm{III}}, \mathrm{As}^{\mathrm{V}}, \mathrm{MA}, \mathrm{DMA}$, and the phosphate, sulphonate and sulphate arsenosugars. Poor separation was achieved for $\mathrm{AB}$ and the glycerol arsenosugar. Therefore a second chromatographic separation (Figure 2b) was employed, which was a modified version of the isocratic 330 cation method developed by Geiszinger et al. $(2002)^{19}$ for the measurement of $\mathrm{AB}$ and the glycerol arsenosugar. The cation exchange system used $10 \mathrm{mM}$ pyridine at $\mathrm{pH} 2.26$, adjusted with formic acid and an isocratic flow rate of $1.5 \mathrm{ml} \mathrm{min}^{-1}$. An injection volume of $100 \mu 1$ was used for both systems.

${ }_{335}$ The ICP-MS when coupled to the HPLC was operated in single ion monitoring mode for $\mathrm{m} / \mathrm{z} 75$, with a dwell time of $100 \mathrm{~ms}$. Peak areas were initially calculated from resultant chromatograms using PeakFit V4.0 chromatography software (Seasolve Software, USA). Quantified data was produced by 340 inclusion of a blank (deionised water) and calibrant standards for each As species from 2 to $50 \mu \mathrm{g}^{-1}$ in each analytical run. Isolated arsenosugar standards were utilised for the identification of arsenosugars by retention time matching. The calibration curve of MA was used for the quantification of the ${ }_{345}$ phosphate, sulphonate and sulphate arsenosugars ${ }^{28}$. MA was used as an appropriate calibrant for these three arsenosugars, since it eluted within the same eluent concentration of $4 \mathrm{mM}$ $\mathrm{NH}_{3} \mathrm{NO}_{3}$. The glycerol arsenosugar was calculated from the cation exchange method. The first method using gradient 350 elution was validated as a routine method for measuring $\mathrm{As}^{\mathrm{III}}$, $\mathrm{As}^{\mathrm{V}}, \mathrm{MA}, \mathrm{DMA}$ and $\mathrm{AB}$ in water samples ${ }^{32}$ with limits of detection based on $3 \sigma$ for blank values (AB: $1.3, \mathrm{As}^{\mathrm{III}}: 0.8$, As ${ }^{\mathrm{V}}: 1.5$, MA: 0.7, DMA: $0.3 \mu \mathrm{g}^{-1}$ ).

For the measurement of these arsenic species in earthworm 355 solutions, analytical measurements were monitored using human urine CRM 18 certified reference material (NIES, Japan) giving a recovery of $97 \pm 10 \%$ and $100 \pm 11 \%$, against certified values for $\mathrm{AB}$ and DMA, respectively. . The extract for CRM tuna fish tissue (BCR, Brussels) was 360 analysed throughout each analytical run. Mean recoveries of $95 \pm 7 \%(\mathrm{n}=3)$ and $80 \pm 0.3 \%(\mathrm{n}=2)$ were obtained for $\mathrm{AB}$ and DMA respectively.

\section{Results and Discussion}

365

\section{Total Arsenic Concentrations}

Arsenic concentrations in soils found in and around the mine varied significantly depending on their proximity to the main tailings. The total arsenic concentrations in the soils from ${ }_{70}$ Devon Great Consols (DGC) were in the range of 255 to $12,466 \mathrm{mg} \mathrm{kg}^{-1}$, extremely high in comparison to the control site (Notts 1) containing levels of arsenic at $16 \mathrm{mg} \mathrm{kg}^{-1}$.

The total arsenic concentrations in the earthworms at DGC and the control site (Notts 1) are shown in Table 1. For L. 375 rubellus the values were 11 to $595 \mathrm{mg} \mathrm{kg}^{-1}$ at the DGC site and $7 \mathrm{mg} \mathrm{kg}^{-1}$ at the control site. The values for D. rubidus at DGC were 17 to $317 \mathrm{mg} \mathrm{kg}^{-1}$ and $7 \mathrm{mg} \mathrm{kg}^{-1}$ at the control site. L. rubellus earthworms were predominantly collected from soils of higher arsenic concentration and had a higher body 380 burden compared to D. rubidus. However, the earthworm tissue concentrations were lower than measured in the host soil providing no indication of bioconcentration of arsenic by the earthworms. L. rubellus had a median worm / soil bioaccumulation factor (BAF) of 0.09 and 0.08 for D. rubidus, 385 marginally higher than found by Langdon et al. $(2003)^{10}$ with a BAF of 0.07 in L. rubellus. At similarly high arsenic soil concentrations as that described in Langdon et al. $(2003)^{10}$ $\left(8,930 \mathrm{mg} \mathrm{kg}^{-1}\right.$, BAF 0.07) the BAF value in the current work was slightly lower $\left(12,466 \mathrm{mg} \mathrm{kg}^{-1}\right.$, BAF 0.03). Earthworms 390 from the control site with a lower soil arsenic content had relatively higher BAF compared to some of the contaminated DGC collection points (Table 1). The higher BAF values where soil arsenic is relatively low have been reported elsewhere in the literature ${ }^{14}$, suggesting that elimination rates 395 of arsenic may be increased at higher concentrations of arsenic and bioaccumulation of arsenic is non-linear ${ }^{18}$.

D. rubidus were generally collected from separate collection points to L. rubellus, with two exceptions. Earthworms of both species at the same collection point at 400 DGC 11 with elevated arsenic levels in the soil had differing BAF values ( 0.04 for $\mathrm{L}$. rubellus and 0.13 for $\mathrm{D}$. rubidus), which might suggest differences in uptake, storage or elimination of arsenic between the two earthworm species or more likely confirm that the bioaccumulation rate is non405 linear at elevated soil arsenic concentrations. This becomes apparent through the comparison of the cast material egested from the earthworm and the host soil. L. rubellus which was mainly found close to the soil surface and often within a layer of vegetation or leaf litter did not bioaccumulate arsenic to 410 any significant degree at sites with high soil arsenic concentrations. For example, soil at DGC 6 contained arsenic at $12,466 \mathrm{mg} \mathrm{kg}^{-1}$, whereas cast material was significantly lower at $923 \mathrm{mg} \mathrm{kg}^{-1}$. The earthworm tissue did not contain equivalent arsenic concentrations, at $359 \mathrm{mg} \mathrm{kg}^{-1}$. Both of 415 these factors suggest that L. rubellus collected at DGC 6 and other sites with similar patterns (e.g. DGC 12 and 13) did not have a low BAF due to egestion of high arsenic concentrations in the cast material, L. rubellus was simply not exposed directly to the high soil arsenic concentrations. However, D. 420 rubidus provided cast material with arsenic concentrations similar to the host soil at most of the sites, with cast material concentrations representing $93 \pm 15 \%$ of the host soil. This would suggest that D. rubidus was directly exposed to the host soil, particularly when compared to L. rubellus (cast material 425 contained $55 \pm 29 \%$ of total arsenic found in host soil). These 
differences between the two earthworm species were not observed at the control site $\left(16 \mathrm{mg} \mathrm{kg}^{1}\right)$ where BAFs were similar for both $\mathrm{L}$. rubellus and D. rubidus at 0.41 and 0.44 respectively but significantly higher than BAFs at the 430 contaminated sites.

Soil $\mathrm{pH}$ for the contaminated soils were slightly acidic and ranged from 3.9 to 5.7. Host soils from the control site had an almost neutral $\mathrm{pH}$ of 6.8 . No significant correlation was observed between earthworm BAFs and soil $\mathrm{pH}$. The organic 435 matter content of the soil (\% LOI) varied at DGC from 6 $36 \%$ with $21 \%$ at the control site. Again, no significant correlation was observed between soil organic matter and earthworm BAFs.

440

\section{Earthworm Arsenic Speciation}

The methanol extraction of arsenic from earthworm tissue resulted in total recoveries of 27 to $81 \%$ (mean $49 \%$ ) for L. rubellus and 31 to $82 \%$ (mean $58 \%$ ) for D. rubidus. The 445 extraction efficiency compared favourably to the $25 \%$ extraction efficiency reported by Geiszinger et al. (2002) ${ }^{19}$.

The measurement of arsenic species was achieved using the gradient anion exchange system for DMA, MA, $\mathrm{As}^{3+}, \mathrm{As}^{5+}$, three arsenosugars (phosphate, sulphonate and sulphate)

450 (Figure 2a) and the cation exchange system was used for $\mathrm{AB}$ and one arsenosugar (glycerol) (Figure 2b) due to their coelution using the gradient system. The data in Table 2 shows the sum of arsenic species measured in the earthworm methanol extracts. These values generally agree with the total 455 arsenic measured in the extract for D. rubidus $(96 \pm 20 \%)$ and L. rubellus $(74 \pm 24 \%)$. The variability in the sum of speciated arsenic in the extract is significantly closer to the total arsenic content of the extract than recoveries reported by Langdon et al. $(2002)^{18}(54 \pm 20 \%)$.

460 Arsenic residing in both species of earthworm was generally in the form of $\mathrm{As}^{\mathrm{V}}$ and $\mathrm{As}^{\mathrm{III}}$, with the main quantifiable organic species being $\mathrm{AB}$, agreeing with the findings of Langdon et al. (2003) ${ }^{15}$. D. rubidus populations demonstrated a higher proportion of $\mathrm{AB}$ (mean $26 \%$ ) 465 compared to L. rubellus (mean $5.5 \%$ ), although where both species of earthworm were collected from the same collection point the proportion of $\mathrm{AB}$ in either earthworm was within 4 $\%$ of each other. However, the occurrence of $\mathrm{AB}$ in the earthworms is more likely to be a factor of total arsenic 470 concentrations in the soil and earthworm tissue rather than being dependent on earthworm species. Earthworms of both species exhibit a higher proportion of $\mathrm{AB}$ at the lower range of total arsenic concentrations in the earthworm tissue. This is particularly evident for D. rubidus from DGC 4, 7 and 9, 475 where $\mathrm{AB}$ accounts for 50,35 and $39 \%$ of the arsenic speciated, respectively. The difference between earthworm species is generally due to L. rubellus residing in soils of higher arsenic concentration compared to D. rubidus and as a result exhibiting relatively less $\mathrm{AB}$ as a proportion of arsenic 480 in the tissue.

MA and DMA occurred at low levels in the earthworms at all sites, generally $1 \%$ or less of the combined sum of arsenic species. Three arsenosugars (glycerol, phosphate and sulphate) were detected as minor constituents in both $\mathrm{L}$.
485 rubellus and D. rubidus, although not necessarily all three arsenosugars for every site (Table 2). The sulphonate arsenosugar was not detected in any of the earthworm extracts.

For the control earthworm (Notts 1 site) combined organic 490 species values accounted for $45 \%$ of arsenic species measured in L. rubellus and $54 \%$ in D. rubidus, and of this arsenosugars accounted for 28 and $34 \%$, respectively. Three individual arsenosugars were present in L. rubellus as $7 \%$ glycerol and $21 \%$, phosphate and for D. rubidus, $16 \%$ 495 glycerol and $18 \%$ phosphate. These findings differ from the study of Geiszinger et al. (2002) ${ }^{19}$, who used control earthworms of similar arsenic tissue concentration $(6 \mathrm{mg} \mathrm{kg}$ ${ }^{1}$ ), but of a different species (L. terrestris), a deep burrowing surface feeder, compared to a surface living and surface 500 feeding species in the case of both L. rubellus and D. rubidus. Arsenic species were apportioned in L.terrestris as mainly two arsenosugars (55\% phosphate and $8 \%$ glycerol), with $5 \%$ DMA, $2 \%$ MA and $18 \%$ inorganic arsenic.

Across all sites (contaminated sites at DGC), organic 505 species accounted for $9 \%$ (mean) of arsenic species for $\mathrm{L}$. rubellus and $32 \%$ (mean) for $\mathrm{D}$. rubidus, with arsenosugars present as minor constituents and accounting for a mean of 3 $\%$ and $5 \%$ of arsenic species, respectively. High levels of the phosphate arsenosugar were only found present in L. rubellus 510 at sites DGC 11 and Notts 1 (Table 2). The sulphate arsenosugar accounted for less than $1 \%$ of arsenic species for each earthworm species across all DGC sites.

Arsenic speciation data presented in Table 2 was compiled from the use of both anion and cation exchange 515 chromatography, in line with common approaches reported in the scientific literature ${ }^{19,28,33}$. Co-elution of the glycerol and AB species by gradient anion exchange was confirmed by the cation exchange method. The gradient program for the anion exchange method was modified to resolve the two peaks, 520 through adjustment of the gradient switchover times from eluent A to B. The time taken for the switchover (starting at 2 minutes) from A to B was phased over 2 minutes rather than 1 minute at the beginning of the elution program. The resulting chromatogram for a representative earthworm extract is ${ }_{525}$ shown in Figure $2 \mathrm{c}$ for the 4 arsenosugars, $\mathrm{As}^{\mathrm{V}}, \mathrm{As}^{\mathrm{III}}, \mathrm{AB}$, MA and DMA measured in one solution, using one chromatographic set-up.

\section{Conclusions}

Findings suggest that earthworms accumulate arsenic, but on 530 the whole do not bioconcentrate arsenic. Whilst the arsenic body burden mainly resides as arsenate and arsenite, the earthworms may be able to eliminate or reduce the toxicity effects when accumulating arsenic in their tissues. For example, the presence of $\mathrm{AB}$ and other organic arsenic species 535 or arsenic metabolites, such as arsenosugars may point to the mechanisms for coping with exposure to soil bound arsenic. Some differences in this process and occurrence of organoarsenicals between species of earthworms is probably due to variations of exposure and uptake, such as feeding 540 patterns and dermal uptake. The range of chromatographic measurements incorporating anion and cation exchange eluent 
systems and the identification of three arsenosugars (glycerol, phosphate, sulphate) in earthworms has helped to define the metabolites, the means of arsenic elimination / sequestration / ${ }_{545}$ exposure patterns, and the differences between earthworm species. The majority of arsenic residing in earthworm tissue was inorganic arsenic, although for uncontaminated soil (Notts 1) up to $45 \%$ of arsenic was present as organoarsenicals in L. rubellus and $54 \%$ in D. rubidus. This 550 was of particular interest, because L. rubellus generally resided in soils at the higher range of arsenic contamination compared to D. rubidus and overall bioaccumulation of arsenic was not significantly different between the two earthworm species. A chromatographic separation was

${ }_{555}$ demonstrated using modified anion exchange gradient elution for the separation of nine arsenic species, including four arsenosugars in one measurement / sample injection, as opposed to the usual approach of using more than one chromatographic set-up.

560

\section{Acknowledgements}

The BGS-NERC university collaboration committee is thanked for the provision of a $\mathrm{PhD}$ studentship for Mark Button. The Tavistock Estate is also thanked for allowing 565 access to the site at the Devon Great Consols. This paper is published with the permission of the Executive Director of the BGS. Professor Francesconi, University of Graz is thanked for provision of some of the standards used in this work.

\section{${ }_{570}$ References}

1. D. J. Spurgeon, J. M. Weeks and C. A. M. Van Gestel, Pedobiologia, 2003, 47, 588-606.

2. T. Jager, R. H. L. J. Fleuren, E. A. Hogendoorn and G. De $575 \quad$ Korte, Environ. Sci. Technol., 2003, 37, 3399-3404.

3. D. J. Spurgeon, S. Lofts, P. K. Hankard, M. Toal, D. McLellan, S. Fishwick and C. Svendsen, Environ. Toxicol. Chem., 2006, 25, 788-796.

4. N. T. T. M. Steenbergen, F. Iaccino, M. De Winkel, L. 580 Reijnders and W. J. G. M. Peijnenburg, Environ. Sci. Technol., 2005, 39, 5694-5702.

5. C. A. M. Van Gestel, W. Ma and C. E. Smit, Sci. Total Environ., 1991, 109-110, 589-604.

6. C. J. Langdon, C. Winters, S. R. Sturzenbaum, A. J. Morgan, 585 J. M. Charnock, A. A. Meharg, T. G. Piearce, P. H. Lee and K. T. Semple, Environ. Sci. Technol., 2005, 39, 2042-2048.

7. J. G. Bundy, D. J. Spurgeon, C. Svendsen, P. K. Hankard, D. Osborn, J. C. Lindon and J. K. Nicholson, FEBS Lett., 2002, 521, 115-120.

$5908 . \quad$ R. E. Arnold, C. J. Langdon, M. E. Hodson and S. Black, Pedobiologia, 2003, 47, 633-639.

9. C. J. Langdon, T. G. Piearce, A. A. Meharg and K. T. Semple, Soil Biol. Biochem., 2001, 33, 1239-1244.

$10 . \quad$ C. J. Langdon, T. G. Piearce, A. A. Meharg and K. T. Semple, $595 \quad$ Environ. Pollut., 2003, 124, 361-373.

11. T. G. Piearce, C. J. Langdon, A. A. Meharg and K. T. Semple, Soil Biol. Biochem., 2002, 34, 1833-1838.

12. C. J. Langdon, T. G. Piearce, S. Black and K. T. Semple, Soil Biol. Biochem., 1999, 31, 1963-1967.

600 13. B. A. Klinck, B. Palumbo, M. R. Cave and J. Wragg, British Geological Survey, 2002, RR/04/003.

14. A. Geiszinger, W. Goessler, D. Kuehnelt, W. Kosmus and K. Francesconi, Environ. Sci. Technol., 1998, 32, 2238-2243.

$15 . \quad$ C. J. Langdon, T. G. Piearce, K. T. Semple, J. Feldmann and

605 A. A. Meharg, Environ. Toxicol. Chem., 2003, 22, 1302-1308.

16. R. Pongratz, Sci. Total Environ., 1998, 224, 133-141.
17. R. Tukai, W. A. Maher, I. J. McNaught and M. J. Ellwood, Anal. Chim. Acta, 2002, 457, 173-185.

18. C. J. Langdon, A. A. Meharg, J. Feldmann, T. Balgar, J. 610 Charnock, M. Farquhar, T. G. Piearce, K. T. Semple and J. Cotter-Howells, J. Environ. Monit. , 2002, 4, 603-608.

19. A. Geiszinger, W. Goessler and W. Kosmus, Appl. Organomet. Chem. , 2002, 16, 473-476.

20. C. B. Hymer and J. A. Caruso, J. Chromatogr., A, 2004, 1045 615 1-13.

21. K. A. Francesconi and D. Kuehnelt, The Analyst, 2004, 129, 373-395.

22. I. Pizarro, M. Gomez, C. Camara and M. A. Palacios, Anal. Chim. Acta, 2003, 495, 85-98.

$62023 . \quad$ Q. Xie, R. Kerrich, E. Irving, K. Liber and F. Abou-Shakra, J. Anal. Atom. Spectrom., 2002, 17, 1037-1041.

24. Y. Martinez-Bravo, A. F. Roig-Navarro, F. J. Lopez and F. Hernandez, J. Chrom. A, 2001, 926, 265-274.

25. A. F. Roig-Navarro, Y. Martinez-Bravo, F. J. Lopez and F. 625 Hernandez, J. Chrom. A, 2001, 912, 319-327.

26. J. L. Gomez-Ariza, D. Sanchez-Rodas and I. Giraldez, J. Anal. At. Spectrom., 1998, 13, 1375-1379.

27. L. O. Iserte, A. F. Roig-Navarro and F. Hernandez, Anal. Chim. Acta, 2004, 527, 97-104.

630 28. A. D. Madsen, W. Goessler, S. N. Pedersen and K. A. Francesconi, J. Anal. At. Spectrom., 2000, 15, 657-662.

29. K. A. Green, S. R. Chenery, T. S. Barlow, H. Taylor and J. M. Cook, 13th Biennial National Atomic Spectroscopy Symposium, 2006, Glasgow, UK.

$63530 . \quad$ L. Wei-Chun, MSc, University of Leicester, 2005.

31. K. A. Francesconi, Appl. Organomet. Chem., 2003, 17, 682683.

32. M. J. Watts, J. O' Reilly, C. A. Smiles and J. M. Cook, British Geological Survey Technical Report, OR/07/021., 2007.

640 33. A. Geiszinger, W. Goessler and W. Kosmus, Appl. Organomet. Chem., 2002, 16, 245-249. 
<smiles>[R]CC(O)COC1OC(C[As](C)(C)=O)C(O)C1O</smiles>

$\begin{array}{ll}\text { Arsenosugar 1 (glycerol) } & \mathrm{R}=\mathrm{OH} \\ \text { Arsenosugar 2 (phosphate) } & \mathrm{R}=\mathrm{OP}(\mathrm{O})(\mathrm{OH}) \mathrm{OCH}_{2} \mathrm{CH}(\mathrm{OH}) \mathrm{CH}_{2} \mathrm{OH} \\ \text { Arsenosugar } 3 \text { (sulphonate) } & \mathrm{R}=\mathrm{SO}_{3} \mathrm{H} \\ \text { Arsenosugar 4 (sulphate) } & \mathrm{R}=\mathrm{OSO}_{3} \mathrm{H}\end{array}$

Figure 1: Structures of the four arsenosugars 
Table 1: Arsenic concentrations in the host soil, earthworm cast material / tissue and bioaccumulation factor $(\mathrm{BAF}=$ worm total As / soil total As).

\begin{tabular}{|c|c|c|c|c|c|c|}
\hline $\begin{array}{l}\text { Sampling } \\
\text { Location }\end{array}$ & $\begin{array}{l}\text { Soil } \\
\text { pH }\end{array}$ & $\begin{array}{c}\text { Soil Organic } \\
\text { Matter (\%) }\end{array}$ & $\begin{array}{c}\text { Total As in } \\
\text { soil }\end{array}$ & $\begin{array}{l}\text { Total As in } \\
\text { worm cast }\end{array}$ & $\begin{array}{l}\text { Total As in } \\
\text { worm }\end{array}$ & BAF \\
\hline L. rubellus & & & $\left(\mathrm{mg} \mathrm{kg}^{-1}\right)$ & $\left(\mathrm{mg} \mathrm{kg}^{-1}\right)$ & $\left(\mathrm{mg} \mathrm{kg}^{-1}\right)$ & \\
\hline Notts $1^{*}$ & 6.8 & 21 & 16 & 11 & 7 & 0.41 \\
\hline DGC 1 & 6.1 & 14 & 2980 & 2488 & 595 & 0.20 \\
\hline DGC 2 & 4.4 & 14 & 1573 & 1330 & 257 & 0.16 \\
\hline DGC 6 & 4.0 & 12 & 12466 & 923 & 359 & 0.03 \\
\hline DGC 10 & 4.3 & 13 & 439 & 284 & 40 & 0.09 \\
\hline DGC $11^{*}$ & 4.6 & 6 & 289 & na & 11 & 0.04 \\
\hline DGC 12 & 3.9 & 30 & 5141 & 1173 & 203 & 0.04 \\
\hline DGC 13 & 5.7 & 36 & 2871 & 1853 & 571 & 0.20 \\
\hline \multicolumn{7}{|l|}{ D. rubidus } \\
\hline Notts $1^{*}$ & 6.8 & 21 & 16 & 11 & 7 & 0.44 \\
\hline DGC 3 & 4.6 & 15 & 1005 & 994 & 317 & 0.32 \\
\hline DGC 4 & 4.2 & 9 & 255 & 274 & 19 & 0.07 \\
\hline DGC 7 & 4.1 & 37 & 331 & 229 & 17 & 0.05 \\
\hline DGC 9 & 4.1 & 11 & 284 & 290 & 18 & 0.06 \\
\hline DGC $11 *$ & 4.6 & 6 & 289 & 291 & 38 & 0.13 \\
\hline DGC 15 & 5.2 & 10 & 913 & 720 & 74 & 0.08 \\
\hline
\end{tabular}

* Both species of earthworm collected from the same site, na sample not available. 
Table 2: Speciated As in the earthworm extracts of L. rubellus and D. rubidus from DGC and a low concentration site (Notts 1

\begin{tabular}{|c|c|c|c|c|c|c|c|c|c|c|c|}
\hline $\begin{array}{l}\text { Sampling } \\
\text { Location }\end{array}$ & $\begin{array}{c}\text { Sum of } \\
\text { speciated } \\
\text { As }\end{array}$ & $\begin{array}{c}\text { Recovery } \\
\text { of species } \\
\text { from } \\
\text { extract }\end{array}$ & $\begin{array}{c}\text { Extraction } \\
\text { efficiency }\end{array}$ & $\mathrm{As}^{\mathrm{V}}$ & $\mathrm{As}^{\mathrm{III}}$ & $\mathbf{A B}$ & DMA & MA & $\begin{array}{c}\text { Sugar-1 } \\
(\mathrm{OH})\end{array}$ & $\begin{array}{c}\text { Sugar-2 } \\
\left(\mathrm{PO}_{4}\right)\end{array}$ & $\begin{array}{c}\text { Sugar-4 } \\
\left(\mathrm{SO}_{4}\right)\end{array}$ \\
\hline L. rubellus & $\left(\mathrm{mg} \mathrm{kg}^{-1}\right)$ & $(\%)^{*}$ & $(\%)^{*}$ & \multicolumn{8}{|c|}{ As species percentage (\%) of total speciated } \\
\hline Notts $1^{* *}$ & 2.9 & 72 & 44 & 19 & 36 & 17 & 0.6 & nd & 6.5 & 21 & nd \\
\hline DGC 1 & 134 & 52 & 36 & 46 & 50 & 2 & 0.2 & 0.5 & 0.5 & nd & 0.9 \\
\hline DGC 2 & 132 & 62 & 63 & 45 & 49 & 5 & 0.2 & 0.5 & 0.3 & nd & 0.6 \\
\hline DGC 6 & 111 & 56 & 42 & 47 & 47 & 2.2 & 0 & 1.5 & 0.2 & nd & 1.2 \\
\hline DGC 10 & 17 & 109 & 27 & 62 & 24 & 13 & 0.2 & 0.7 & 1.1 & nd & nd \\
\hline DGC $11^{* *}$ & 5.6 & 115 & 32 & 57 & 16 & 12 & nd & nd & 6.2 & 8.4 & nd \\
\hline DGC 12 & 127 & 61 & 81 & 51 & 44 & 2.7 & 0.2 & 0.9 & 0.3 & nd & 0.7 \\
\hline DGC 13 & 281 & 63 & 64 & 28 & 69 & 1.8 & 0.1 & 0.3 & 0.4 & nd & 0.5 \\
\hline Mean*** & & 74 & 49 & 48 & 43 & 5.5 & 0.1 & 0.6 & 1.3 & 1.2 & 0.6 \\
\hline $\mathrm{SD}$ & & 24 & 19 & 11 & 18 & 4.9 & 0.1 & 0.5 & 2.2 & 3.2 & 0.4 \\
\hline \multicolumn{12}{|l|}{ D. rubidus } \\
\hline Notts $1^{* *}$ & 3.1 & 79 & 40 & 13 & 33 & 19 & 0.9 & nd & 16 & 18 & nd \\
\hline DGC 3 & 184 & 55 & 82 & 29 & 65 & 5.4 & 0.1 & 0.1 & 0.1 & nd & 0.4 \\
\hline DGC 4 & 7.07 & 101 & 31 & 32 & 6 & 50 & 0.6 & 1.1 & 3.7 & 6.5 & nd \\
\hline DGC 7 & 12.6 & 105 & 54 & 16 & 44 & 35 & 0.8 & 0.7 & 3 & 0.7 & nd \\
\hline DGC 9 & 16.3 & 105 & 77 & 7.9 & 46 & 39 & 0.4 & 0.7 & 5.5 & 0.8 & 0.3 \\
\hline DGC $11^{* *}$ & 30 & 107 & 52 & 24 & 55 & 16 & 0.1 & nd & 3.8 & 0.9 & 0.3 \\
\hline DGC 15 & 82.9 & 102 & 73 & 26 & 60 & 11 & 0.5 & 0.5 & 0.5 & 1.4 & 0.3 \\
\hline Mean*** & & 96 & 58 & 22 & 46 & 26 & 0.4 & 0.5 & 2.8 & 1.7 & 0.2 \\
\hline $\mathrm{SD}$ & & 20 & 19 & 8.0 & 20 & 15 & 0.4 & 0.7 & 1.7 & 2.2 & 0.3 \\
\hline
\end{tabular}


* Recovery of species as a percentage of the total As in the extract, extraction efficiency based on total As in the extract as a percentage of total As in the worm **both species of earthworm collected from the same site, *** mean value does not include Notts 1 except recovery of species and extraction efficiency which do. nd - below limit of quantification or not detected

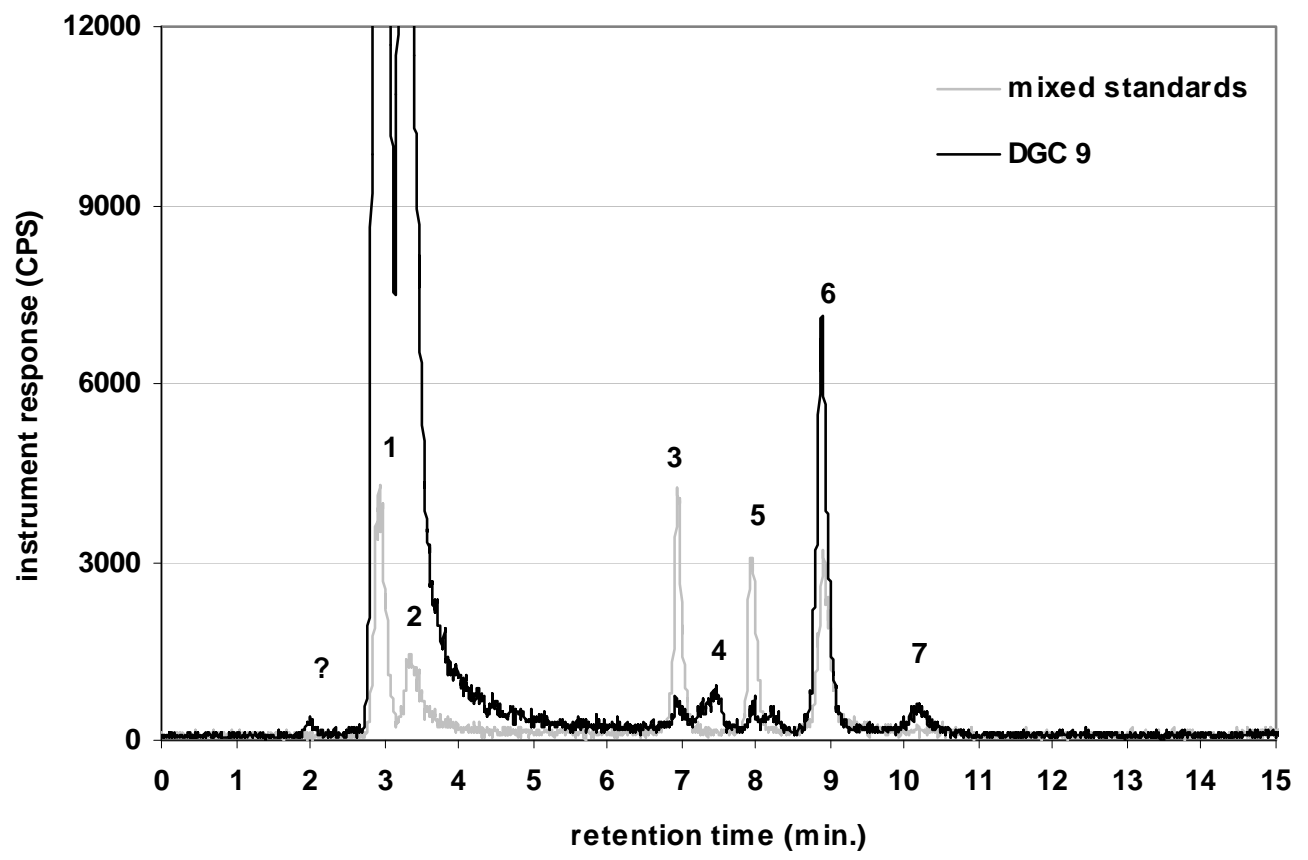

Figure 2 (a): Anion gradient elution profile for a mixed standard solution $\left(2 \mu \mathrm{g} \mathrm{l}^{-1}\right)$ and an earthworm extract (DGC 9 D. rubidus). Peaks 1-7: $1=\mathrm{AB}, 2=\mathrm{As}^{\mathrm{III}}, 3=$ DMA, $4=$ Sugar-2, $5=$ MA, $6=$ AsV, $7=$ Sugar- 4 


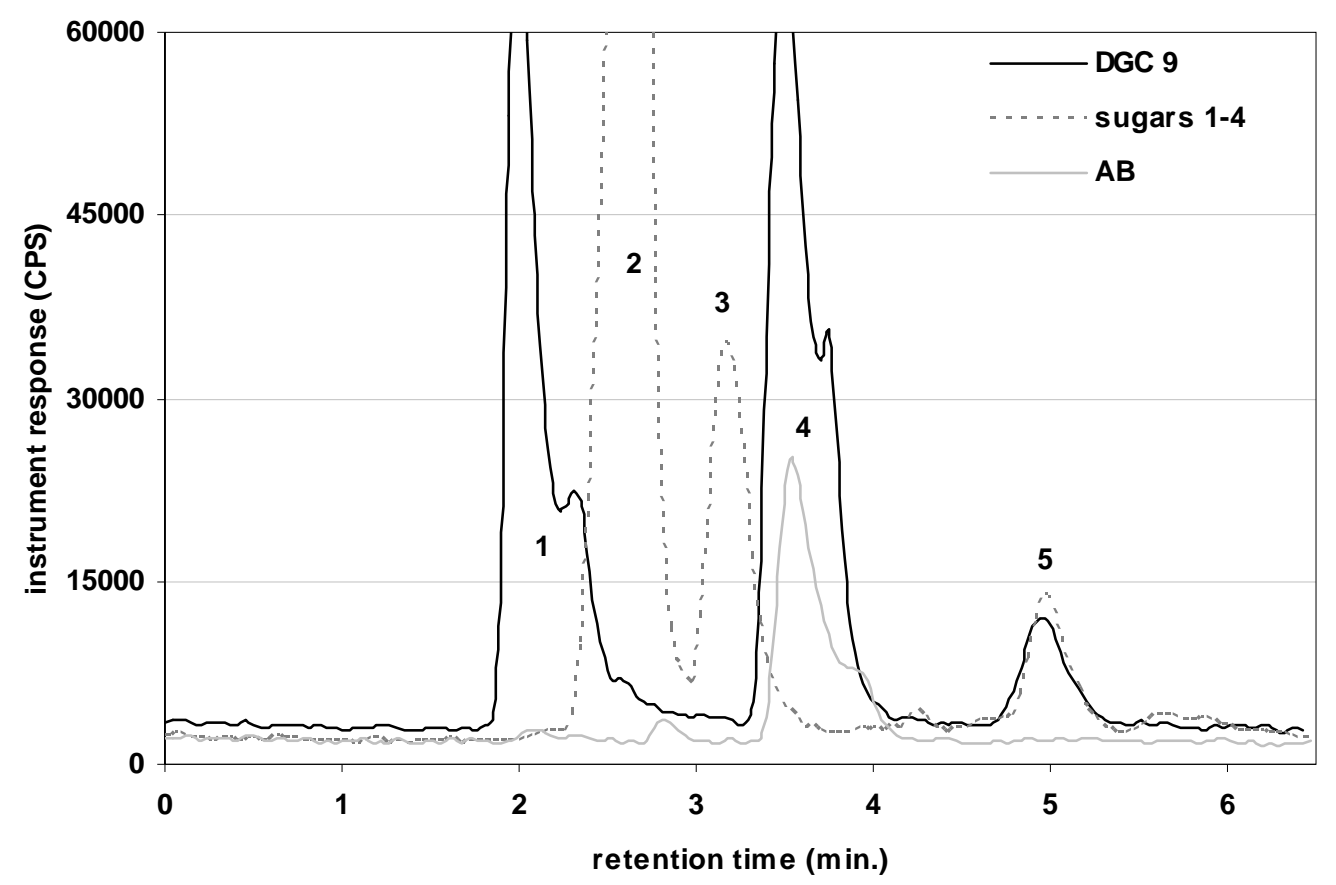

Figure 2 (b): Cation isocratic elution profile for an earthworm extract (DGC $9 \mathrm{D}$. rubidus), an algal extract containing sugars 1-4 and an $\mathrm{AB}$ standard at $\left(13 \mu \mathrm{g}^{-1}\right)$. Peaks 1-5: $1=$ solvent front containing As ${ }^{\mathrm{III}}+\mathrm{As}^{\mathrm{V}}+\mathrm{MA}, 2=\mathrm{DMA}+$ Sugars-2/3, $3=$ Sugar-4, 4 = AB, 5 = Sugar 1 .

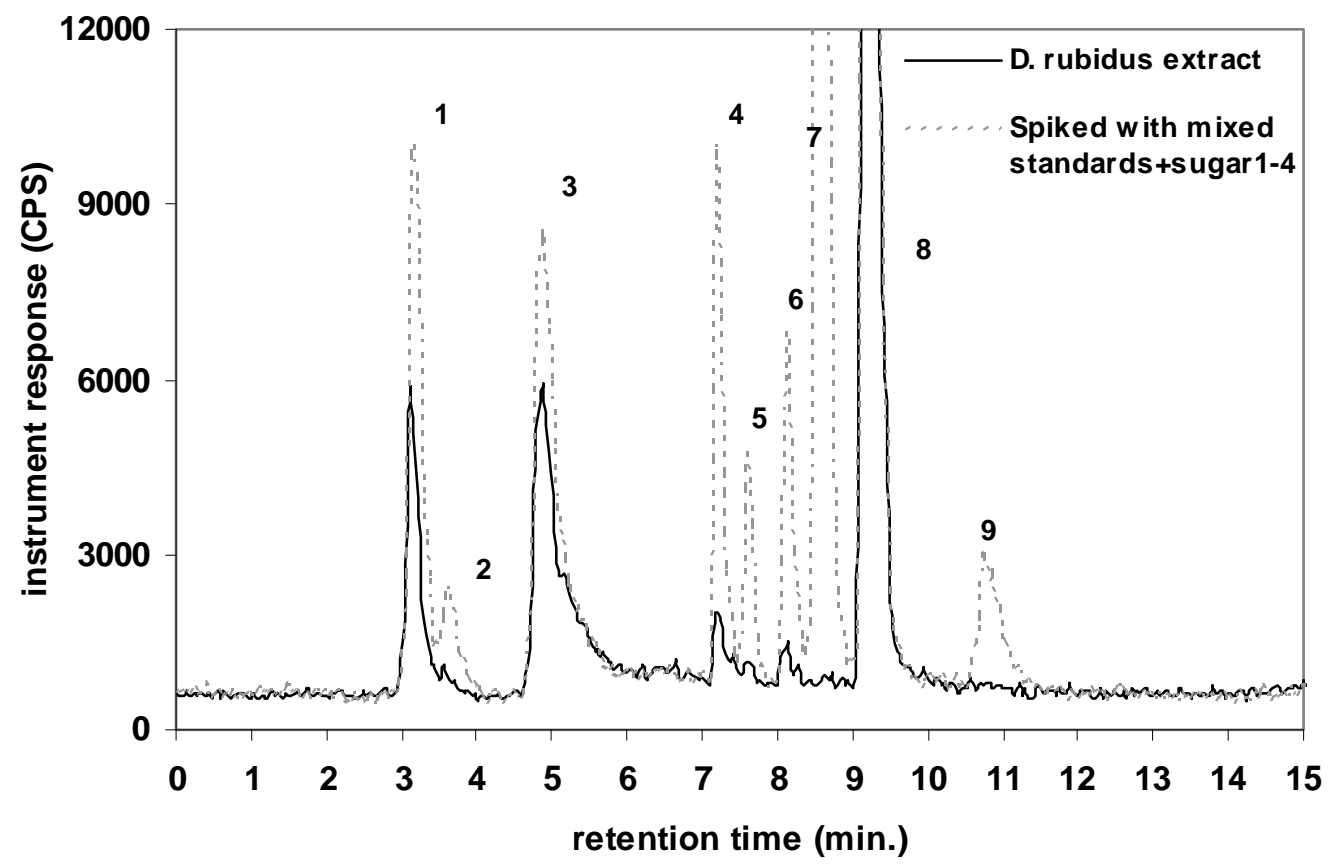

Figure 2 (c): Anion gradient elution profile for a mixed standard solution $\left(10 \mu \mathrm{g} \mathrm{l}^{-1}\right)$ and a representative earthworm extract. Peaks $1-9: 1=\mathrm{AB}, 2=$ Sugar- $1,3=\mathrm{As}^{\mathrm{III}}, 4$ = DMA, 5 = Sugar-2, $6=$ MA, $7=$ Sugar-3, $8=$ As ${ }^{\mathrm{V}}, 9=$ Sugar -4 . 